\title{
MIR29B1 Pre-miRNA
}

National Cancer Institute

\section{Source}

National Cancer Institute. MIR29B1 Pre-miRNA. NCI Thesaurus. Code C82724.

MIR29B1 pre-miRNA is an olig onucleotide that is encoded by the human MIR29B1 gene and has a role in the regulation of gene expression. 